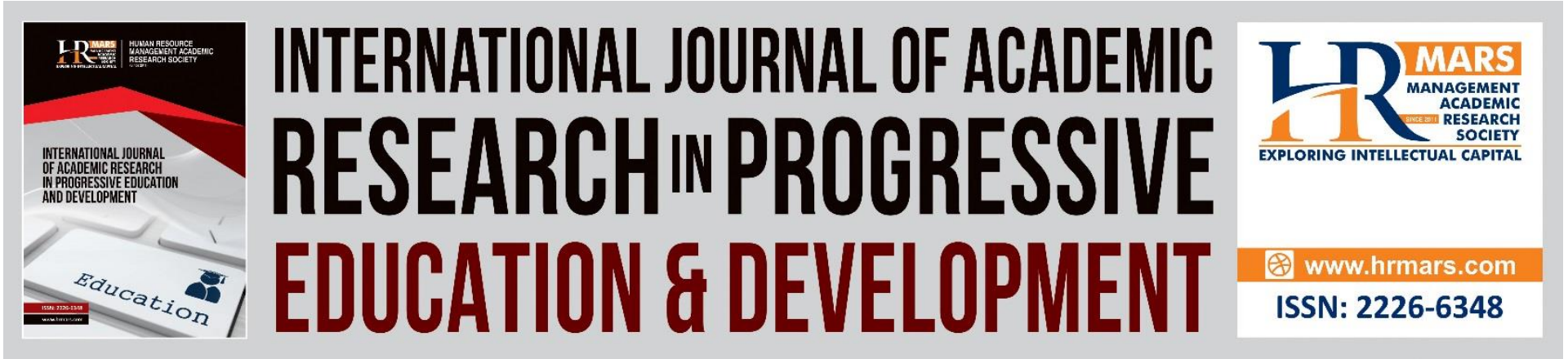

\title{
Road to School Transformation 2025: A Systematic Literature Review on Teacher Autonomy in Malaysia
}

\section{Anniliza Mohd Isa, Al-Amin Mydin, Abdul Ghani Kanesan Abdullah}

To Link this Article: http://dx.doi.org/10.6007/IJARPED/v10-i3/10710

DOI:10.6007/IJARPED/v10-i3/10710

Received: 08 June 2021, Revised: 11 July 2021, Accepted: 19 July 2021

Published Online: 04 August 2021

In-Text Citation: (Isa et al., 2021)

To Cite this Article: Isa, A. M., Mydin, A.-A., \& Abdullah, A. G. K. (2021). Road to School Transformation 2025: A Systematic Literature Review on Teacher Autonomy in Malaysia. International Journal of Academic Research in Progressive Education and Development, 10(3), 34-45.

Copyright: (C) 2021 The Author(s)

Published by Human Resource Management Academic Research Society (www.hrmars.com)

This article is published under the Creative Commons Attribution (CC BY 4.0) license. Anyone may reproduce, distribute, translate and create derivative works of this article (for both commercial and non-commercial purposes), subject to full attribution to the original publication and authors. The full terms of this license may be seen

at: http://creativecommons.org/licences/by/4.0/legalcode

\section{Vol. 10(3) 2021, Pg. 34 - 45}

Full Terms \& Conditions of access and use can be found at http://hrmars.com/index.php/pages/detail/publication-ethics 


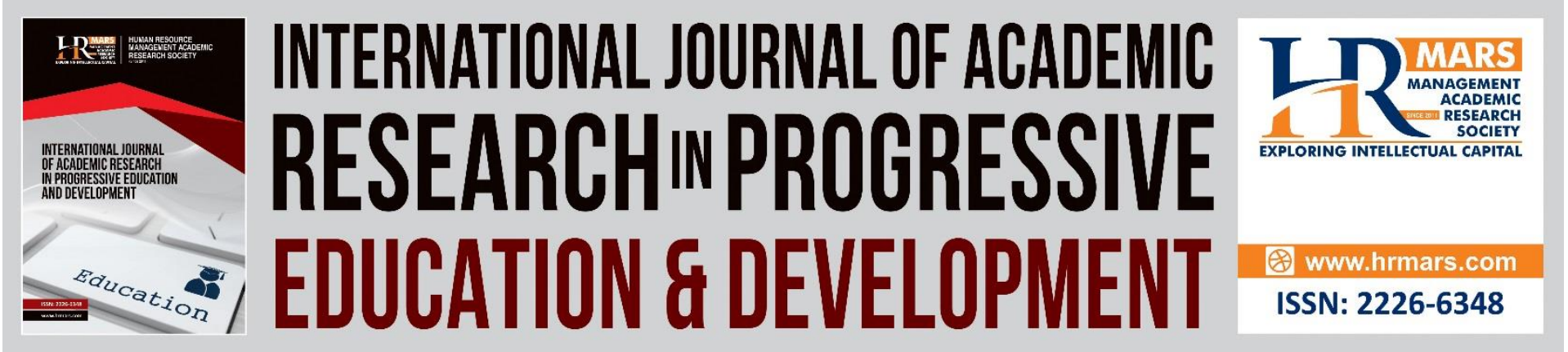

\title{
Road to School Transformation 2025: A Systematic Literature Review on Teacher Autonomy in Malaysia
}

\author{
Anniliza Mohd Isa \\ School of Education Studies, Universiti Sains Malaysia, 11800, USM, Pulau Pinang, Malaysia \\ Email: anniliza@students.usm.my
}

\author{
Al-Amin Mydin, Abdul Ghani Kanesan Abdullah \\ Universiti Sains Malaysia \\ Email: alamin@usm.my, agk@usm.my
}

\begin{abstract}
Teacher autonomy in Malaysia is gaining attention among policy makers, making it a key element in School Transformation Programs (SLP25). However, research on teacher autonomy in Malaysia is still scarce and have minimal interest among social science researchers compared to other countries. The purpose of this study was to collect and analyse previous studies on teacher autonomy in Malaysia. The objective of this study was to investigate the extent, issues, and challenges of teacher autonomy in Malaysia. There were three research questions in this review, (1) How was teacher autonomy level in Malaysia? (2) What type of teacher autonomy implemented in Malaysia? and (3) What are the issues and challenges faced by Malaysian teachers regarding teacher autonomy? To address the research questions, a systematic literature review was performed using four-phase in Preferred Reporting Items for Systematic Reviews and Meta-analyses (PRISMA). Findings show that despite excercising guided autonomy, teachers in Malaysia show an encouraging level of autonomy. Overall, the main challenges related to teacher autonomy are teachers' attitudes and behaviours toward given autonomy.
\end{abstract}

Keywords: Teacher Autonomy, School Transformation Program, Autonomous Teacher, Autonomy, Decision-Making Teacher, SLR

\section{Introductions}

Various changes are made under the Malaysian Education Development Plan (MEDP) 2013-2025 to transform the national education landscape to be more holistic and aims to improve the quality of education. One of the major programs is the 2025 School Transformation Program (STP25) which has been implemented since 2015. The three objectives of STP25 are to apply the best teaching concepts and practices, develop internal expertise through comprehensive structured training for pedagogical and leadership 
counsellors, and develop an effective learning environment by prioritizing student development. Based on the STP25 module, one of the key element in best teaching practice is teacher autonomy (BPG, 2015). The previous study had shown that teacher autonomy contributing to school best practices, and produce a positive impact on teachers especially in commitment, job satisfaction, discipline and attendance (Zhou et al., 2019; Esfandiari \& Kamali, 2016). According to Devjak et al. (2021) autonomy is one of the most important organisational principles of the public education system that connected to monitoring and quality assurance in the field of education.

Control and freedom are general concepts commonly associated with autonomy. For teachers, the belief that they can control teaching-related tasks is important to perform their duties as teachers more excellently. This belief made autonomy an individual's internal factors that motivate him to take actions based on external sources that have a positive impact on behaviour (Deci \& Ryan, 2008). Autonomy also defined as the freedom and independence of individual work, including also in collaborative decision making as well as freedom in making choices in his field (Vangrieken et al., 2017) especially work-related (Fallis, 2005). With autonomy in the field of work, employee self-development and intrinsic motivation can be enhanced (Zhou et al., 2019).

Autonomy in education begins with school-based management where the school is given autonomy in making decisions related to management with the involvement of teachers, parents and the community (Mohd Isa et al., 2020). The involvement of teachers in decision making related to school management allows teachers to extend their autonomy from the classroom to the school organization as a whole which contributes to the improvement of teacher professionalism. In other words, teacher autonomy can be defined as professional responsibility and independence and willingness with the character of autonomous teachers that is self-reflection, open to professional and personal development, competent, independent, and responsible (Duyen, 2019).

Teacher autonomy is the most important aspect of teacher professionalism (Paulsrud \& Wermke, 2019; Ulas \& Aksu, 2015; Varatharaj et al., 2015) where the teacher can control the teaching and the environment (Rudolph, 2006) and is a motivating factor to job satisfaction (Gwatney, 2012; Pearson \& Moomaw, 2005). Recognizing the accountability of the results of this autonomy, teachers will be more motivated and will be more responsible for their duties (Zhou et al., 2019), improve self-performance (Ulas \& Aksu, 2015), perform their duties brilliantly (Varatharaj et al., 2015) and have the freedom to carry out tasks such as assessment and evaluation without problems (Ali \& Arsaythamby, 2017).

Overall, it was found that teacher autonomy has a direct positive impact on various aspects of education. Autonomous teachers are more motivated, high job satisfaction because they can control their field of work, increased commitment and self-efficacy which ultimately contributes to positive behaviour in the organization as well as impact the success of any form of transformation in education. However, the risk for highly autonomous teachers is in their practice that overwhelmed freedom in decision making causes teachers to act according to their wishes and lack cooperation and collaboration (Mohd Isa et al., 2020). Meanwhile, low levels of autonomy are feared to have the opposite effect such as 
demotivation, lack of self-confidence, low self-esteem that contribute to de-professionalism in teachers (Paulsrud \& Wermke, 2019) and will indirectly affect school happiness. This is due to previous studies that prove there is a significant positive correlation between school happiness and teacher autonomy (Al-Bataineh et al., 2021)

Compared to foreign countries such as Finland and Sweden, where teachers exercise high autonomy especially with teaching and learning (Paulsrud \& Wermke, 2019), Malaysia adopting a form of guided autonomy (Ismail \& Abdullah, 2014) where the autonomy given to schools still needs to comply with education department guidelines which indirectly control and limit autonomy. Reliance on detailed guidelines such as curriculum scripts (Southern, 2018), rigid monitoring from the administrative levels, district, and state education officers contributed to the decline in teacher autonomy (Kim, 2018). Indirectly, this situation leads to a decrease in the level of teachers professionalism (Paulsrud \& Wermke, 2019) who then impact schoolwork performance and effectiveness.

Although teacher autonomy plays an important role in STP25, it is found that research on teacher autonomy in Malaysia is still scarce and have minimal interest among social science researchers when compared to other countries. Hence, there is a need to conduct a literature review related to previous studies on teacher autonomy in Malaysia.

\section{Objectives}

The purpose of this study was to collect and analyse previous studies on teacher autonomy in Malaysia. The objective of this study was to investigate the extent, issues, and challenges of teacher autonomy in Malaysia. There were three research questions in this review, (1) How was teacher autonomy level in Malaysia? (2) What type of teacher autonomy implemented in Malaysia? and (3) What are the issues and challenges faced by Malaysian teachers regarding teacher autonomy? Thus, this study is expected to contribute to describing the autonomy of Malaysian teachers.

\section{Methods}

To address the research questions, a systematic literature review was performed using four-phase in Preferred Reporting Items for Systematic Reviews and Meta-analyses (PRISMA) (Moher et al., 2009) as shown in figure. 1. The research process began with the identification phase; online searches using databases such as SCOPUS, and Google Scholar with the help of Open Athens. Keywords in Malay and English such as teacher autonomy, autonomous teacher, and decision-making teacher were used to search for relevant studies. In addition to searching for indexed journal articles, conference proceedings, unpublished Ph.Ds. theses, books, and government documents were also considered. There were, however, a limited number of past studies on teacher autonomy in Malaysia. A total of 557 studies were found through database searching in SCOPUS and another 748 studies from GOOGLE SCHOLAR. 103 duplicate articles removed, thus 1202 studies undergo the next phase. In the screening phase, the scope of the search was narrowed down to several criteria; articles of related studies had been published from 2010 to the present, available in the full text and the context of these past studies was teacher autonomy. A total of 719 studies excluded after the screening process and only 71 studies were assessed in the third phase, eligibility using the PRISMA 
DEVELOPMENT

Vol. 10, No. 3, 2021, E-ISSN: 2226-6348 @ 2021 HRMARS

checklist. Finally, 7 studies located in Malaysia included and independently summarized their scope, methods, samples, location and type of school.

Figure 1

PRISMA flowchart for a systematic review on teacher autonomy in Malaysia

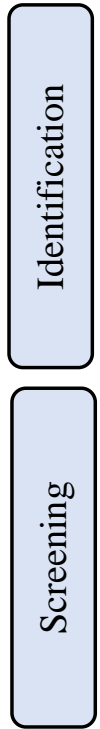

$$
\begin{gathered}
\text { Records identified through } \\
\text { database searching (SCOPUS) }
\end{gathered}
$$
$(\mathrm{n}=557)$

Records identified through database searching (GOOGLE SCHOLAR) $(n=748)$
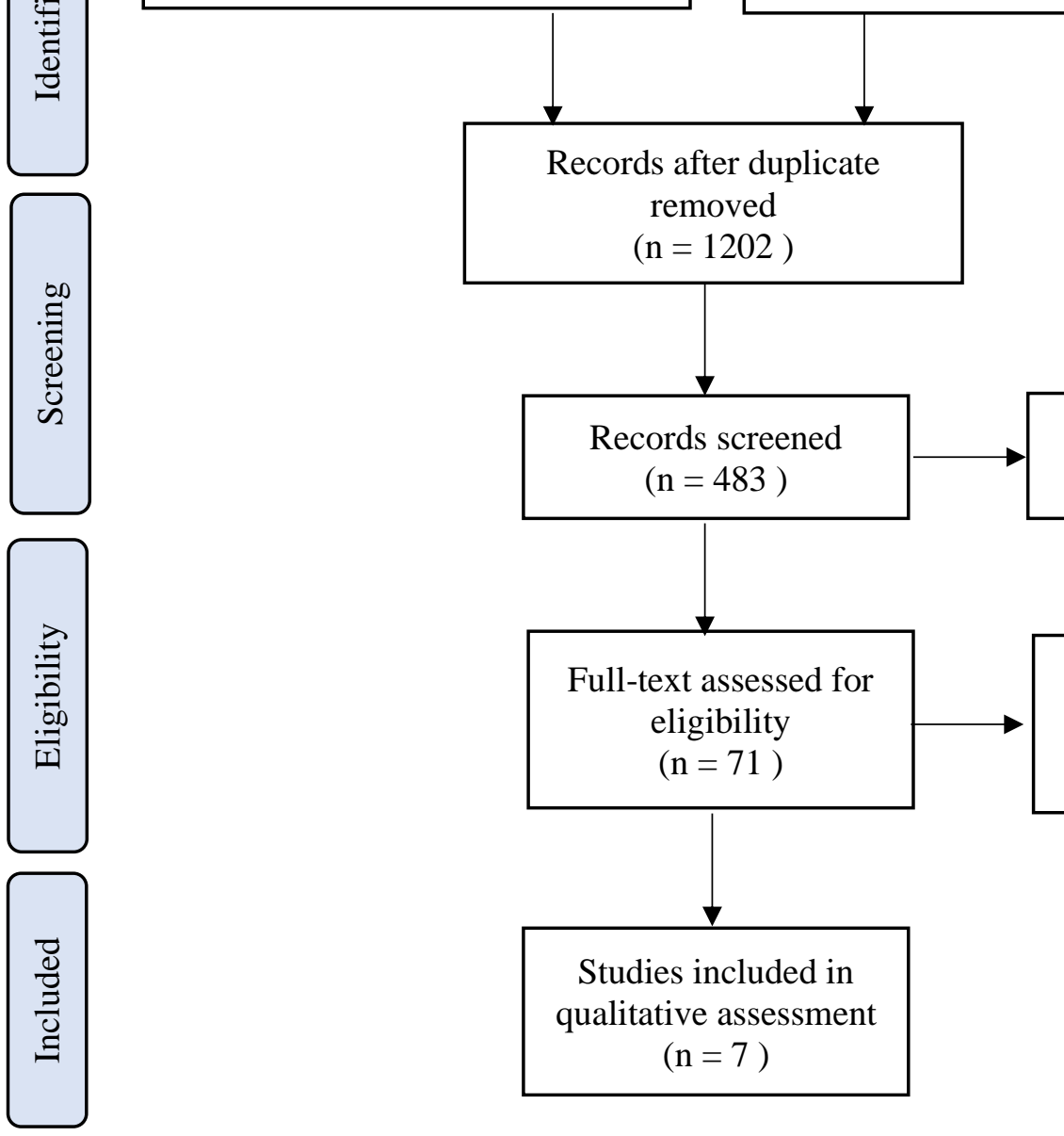

Records excluded $(n=719)$

Full text articles excluded with reasons $(\mathrm{n}=64)$

\section{Findings}

Summaries of the previous study

7 studies included in this study (Ali et al., 2019; Mohd Isa et al., 2020; Ismail \& Abdullah, 2014; Tehrani \& Mansor, 2012; Varatharaj, 2015, 2018a, 2018b) are summarized in table 1. All studies summarized according to scope, methods, samples, location and type of school. Teacher autonomy related scope reviewed are empowerment and autonomy in $21^{\text {st }}$ century teaching and learning (Abdul Jalil Ali et al., 2019), autonomy, accountability and teacher readiness (Ismail \& Abdullah, 2014), teacher autonomy in primary school classroom assessment (Mohd Isa et al., 2020), teacher autonomy and assessment in cluster school (Varatharaj, 2015), assessment in the $21^{\text {st }}$-century classroom and teacher autonomy 
DEVELOPMENT

Vol. 10, No. 3, 2021, E-ISSN: 2226-6348 @ 2021 HRMARS

(Varatharaj, 2018a), teacher perception and acceptance in autonomy (Varatharaj, 2018b) and teacher autonomy in obtaining knowledge (Tehrani \& Mansor, 2012).

As for method or approach, 3 studies are using mixed-methods (Ismail \& Abdullah, 2014; Varatharaj, 2015, 2018b), 2 quantitative approaches (Ali et al., 2019; Mohd Isa et al., 2020) and 2 qualitative approaches (Tehrani \& Mansor, 2012; Varatharaj, 2018a). The sample for all studies was comprised of school teachers. Based on the type of school, 3 studies done in cluster school (Ismail \& Abdullah, 2014; Varatharaj, 2015, 2018a), 3 studies in national secondary school (Ali et al., 2019; Tehrani \& Mansor, 2012; Varatharaj, 2018b), and only 1 studies done in national primary school (Isa et al., 2020). In terms of locations, 5 studies conducted in north peninsular Malaysia mostly in Perak, Kedah, Perlis, Pulau Pinang(Ali et al., 2019; Ismail \& Abdullah, 2014; Varatharaj, 2015, 2018a, 2018b) while one in Johor (Tehrani \& Mansor, 2012) and another one in Sabah (Isa et al., 2020).

Next, there are several limitations identified such as location, sample, type of school, scope and researcher. The majority of previous studies were conducted in peninsular Malaysia, only one in Sabah and none in Sarawak. This shows that researchers in peninsular Malaysia, especially in the northern part, have a higher interest in this field than researchers in Sabah and Sarawak. The study sample focused only on teachers and there were no views from school leaders as well as district education officers who were the monitors and mentors to the teachers. Given that the concept of teacher autonomy is a national issue that needs to be practised by all teachers in Malaysia, the study should not focus on cluster schools only. More research needs to be done in national primary and secondary schools as well as in vernacular schools. Comparative studies in teacher autonomy on different types of schools such as a public school and a vernacular school or between urban and rural schools should be done to identify the strengths and weaknesses of the practice.

In addition, previous studies related to teacher autonomy in Malaysia are seen to be limited to teacher empowerment, assessment and perception. The scope of the study can be further expanded by examining the relationship of teacher autonomy with leadership, school management, professional development, self-efficacy, decision making, organizational behaviour, commitment and many more. A model of teacher autonomy can also be constructed in addition to impact studies on student achievement and school performance.

Given that teacher autonomy in STP25 is highly emphasized, then a study of the effectiveness of STP25 on increasing teacher autonomy is necessary. The scope of the study covers the impact of STP25 on teacher autonomy is important to ensure that the planned program is implemented accurately per the objectives outlined. 
Table 1

Summaries of previous studies

\begin{tabular}{|c|c|c|c|c|c|c|}
\hline No. & Authors & Scope & Methods & Sample & Location & $\begin{array}{l}\text { Type of } \\
\text { school }\end{array}$ \\
\hline 1 & $\begin{array}{c}\text { Ali et al. } \\
\text { (2019) }\end{array}$ & $\begin{array}{l}\text { Empowerment \& } \\
\text { Autonomy in 21st- } \\
\text { century teaching- } \\
\text { learning }\end{array}$ & Quantitative & Teacher & $\begin{array}{l}\text { North } \\
\text { Peninsular, } \\
\text { Malaysia }\end{array}$ & $\begin{array}{l}\text { National } \\
\text { Secondary } \\
\text { school }\end{array}$ \\
\hline 2 & $\begin{array}{l}\text { Ismail \& } \\
\text { Abdullah } \\
\text { (2014) }\end{array}$ & $\begin{array}{c}\text { Autonomy, } \\
\text { accountability \& } \\
\text { teacher readiness }\end{array}$ & $\begin{array}{l}\text { Mixed- } \\
\text { Method }\end{array}$ & Teacher & $\begin{array}{l}\text { North } \\
\text { Peninsular, } \\
\text { Malaysia }\end{array}$ & $\begin{array}{l}\text { Cluster } \\
\text { School }\end{array}$ \\
\hline 3 & $\begin{array}{l}\text { Mohd Isa } \\
\text { et al } \\
(2020)\end{array}$ & $\begin{array}{c}\text { Teacher autonomy } \\
\text { in Classroom } \\
\text { assessment in } \\
\text { Primary school } \\
\text { 'Teacher }\end{array}$ & Quantitative & Teacher & $\begin{array}{l}\text { Sabah } \\
\text { (North } \\
\text { Borneo) }\end{array}$ & $\begin{array}{l}\text { National } \\
\text { Primary } \\
\text { School }\end{array}$ \\
\hline 4 & $\begin{array}{c}\text { Tehrani \& } \\
\text { Mansor } \\
(2012)\end{array}$ & $\begin{array}{l}\text { Autonomy in } \\
\text { Obtaining } \\
\text { Knowledge' on } \\
\text { 'Class Practice' }\end{array}$ & Qualitative & Teacher & $\begin{array}{l}\text { Southern } \\
\text { Peninsular } \\
\text { Malaysia }\end{array}$ & $\begin{array}{c}\text { National } \\
\text { Secondary } \\
\text { School }\end{array}$ \\
\hline 5 & $\begin{array}{c}\text { Varatharaj } \\
\text { (2018a) }\end{array}$ & $\begin{array}{l}\text { Assessment in the } \\
21 \text { st-century } \\
\text { classroom \& } \\
\text { teacher autonomy }\end{array}$ & Qualitative & Teacher & $\begin{array}{l}\text { North } \\
\text { Peninsular, } \\
\text { Malaysia }\end{array}$ & $\begin{array}{l}\text { Cluster } \\
\text { school }\end{array}$ \\
\hline 6 & $\begin{array}{c}\text { Varatharaj } \\
\text { (2018b) }\end{array}$ & $\begin{array}{c}\text { Teacher } \\
\text { perception and } \\
\text { acceptance in } \\
\text { autonomy }\end{array}$ & $\begin{array}{l}\text { Mixed- } \\
\text { Method }\end{array}$ & Teacher & $\begin{array}{l}\text { North } \\
\text { Peninsular, } \\
\text { Malaysia }\end{array}$ & $\begin{array}{c}\text { National } \\
\text { Secondary } \\
\text { School }\end{array}$ \\
\hline 7 & $\begin{array}{l}\text { Varatharaj } \\
\text { et al. } \\
\text { (2015) }\end{array}$ & $\begin{array}{l}\text { Teacher Autonomy } \\
\text { in Classroom } \\
\text { Assessment in } \\
\text { Cluster school }\end{array}$ & $\begin{array}{l}\text { Mixed- } \\
\text { Method }\end{array}$ & teacher & $\begin{array}{l}\text { North } \\
\text { Peninsular, } \\
\text { Malaysia }\end{array}$ & $\begin{array}{l}\text { Cluster } \\
\text { School }\end{array}$ \\
\hline
\end{tabular}

Level of teacher autonomy

The findings of the study found that teacher autonomy in Malaysia is at a moderate to a high level. Moderate levels of teacher autonomy were found in studies by Ali et al. (2019) and Varatharaj $(2015,2018 b)$ while high level of teacher autonomy was found in Isa et al (2020); Ismail and Abdullah (2014) studies. These significant differences may be due to differences in the study population, type of school as well as the implementation of current education policy. Ismail and Abdullah (2014) study, for example, is at a high level because it compares teacher autonomy in autonomous and high-performing schools compared to Ali et al. (2019) that conducted in national schools. The findings of Mohd Isa et al. (2020) study are at a high level because the study was implemented in 2020 after most schools were involved in STP25 under MEDP 2013-2025. Therefore, the expected increase in the level of autonomy among teachers in Malaysia might become a reality if STP25 is successfully implemented. 
DEVELOPMENT

Vol. 10, No. 3, 2021, E-ISSN: 2226-6348 @ 2021 HRMARS

\section{Type of teacher autonomy implemented}

Of all the studies listed, only Ismail \& Abdullah (2014) discusses the type of teacher autonomy in Malaysia. According to Ismail \& Abdullah (2014), the type of autonomy implemented in Malaysia is guided autonomy. Guided autonomy means the practice of teacher autonomy takes place in a controlled environment where there are guidelines that need to be followed. This form of autonomy is different when compared to teacher autonomy in Finland and Sweden where teachers are freer to make decisions related to teaching and learning (Paulsrud, 2018). Teacher's are fully aware of the type of autonomy over the planning and implementing the lesson where teachers have little say over the use of curriculum because of the centralised nature of the curriculum (Varatharaj, 2015). However, through STP25, it is hoped that teachers will have more autonomy in determining teaching and learning in the classroom as well as more freedom to contribute to collective decisions in aspects of school management.

\section{Issues and Challenges}

Overall, based on past studies, the main challenges related to teacher autonomy are teachers' attitudes and behaviours toward given autonomy (Mohd Isa et al., 2020; Ismail \& Abdullah, 2014; Tehrani \& Mansor, 2012; Varatharaj, 2015). Low autonomy leads to a decline in teacher professionalism (Paulsrud \& Wermke, 2019) which then affects teacher motivation, job performance and commitment. Low teacher autonomy indicates that teachers' involvement in decision-making in school is limited which interferes with job satisfaction as well as inhibits the development of teacher creativity and innovation in their teaching (Mohd Isa et al., 2020). This situation can also contribute to the weaknesses and failures of the implementation of policies such as STP25 which require teachers to exercise autonomy in carrying out their daily tasks.

The high level of teacher autonomy presents challenges from different perspectives. In general, high autonomy is influenced by various factors such as teacher education, professional development, current policy requirements, distributive leadership as well as empowerment by the school leader. School leaders need to explore appropriate teacher autonomy empowerment plans in line with 21st-century learning (Ali et al., 2019) so that the teacher can make decisions that have a positive impact on his work (Varatharaj, 2018a). However, the challenge for highly autonomous teachers is in their practice i.e. freedom in decision making causes teachers to be able to act according to their own will and lack of cooperation and collaboration.

Regardless of whether teacher autonomy is high or low, teacher attitudes play a major role. An attitude that does not want to accept change or is resistant (Al Salami et al., 2017) affect the implementation of the transformation of a policy such as STP25. The attitude of rejecting changes in low autonomy teachers such as rejecting sub-unit positions in organizations or programs, not wanting to attend courses or workshops and not engaging in professional development programs. Resistant teachers with high autonomy are teachers who carry out tasks according to their wishes ie still conducting examinations even though it has been abolished because they are accustomed to examination-oriented assessment, not cooperating on disagreed decisions, and overconfidence in decision-making and ignoring the views of others. 


\section{Discussions}

Despite practising guided autonomy, teachers in Malaysia show moderate to high levels of autonomy. This is an interesting finding in this study because, despite the implementation of autonomy in a controlled environment, teachers still feel free to determine the direction of teaching and learning. Thus, it proves that the teacher's behaviour is either positive or resistant to perceive autonomy which affects their level of autonomy. Teacher autonomy means that teachers can teach independently, or have the ability, freedom or responsibility to choose the teaching issues related to themselves (Guan, 2021). Autonomous teachers will be more motivated, high job satisfaction because they can control their field of work, increased commitment and self-efficacy which ultimately contributes to positive behaviour in the organization as well as impact the success of any form of transformation in education such as STP25 in Malaysia. To achieve the aspirations of STP25, school administrators need to be sensitive and efficient in enabling teachers to carry out their duties with trust and honesty and committed to achieving the goal of becoming students through the improvement of academic achievement in line with values. Awareness of increasing accountability along with the granting of autonomy should always be emphasized so that teachers can always maintain their level of professionalism with commitment and integrity (Isa et al., 2020).

Further research on teacher autonomy is necessary to increase knowledge related to this field, especially in Malaysia. The very small number of studies involving only minimal institutions indicates that teacher autonomy is not an issue of choice among Malaysian researchers. However, following the transformation in education that increasingly emphasizes holistic and sustainable education, teacher autonomy plays a crucial role in changing the educational landscape in Malaysia. Therefore, it is suggested that studies related to teacher autonomy should be multiplied and expanded in scope to bring about significant changes in perceived teacher autonomy to be on par with foreign countries such as Finland and Sweden.

\section{Conclusion}

Teacher autonomy in Malaysia is gaining attention among policymakers making it a key element in school transformation programs. Despite exercising guided autonomy, teachers in Malaysia show an encouraging level of autonomy. Meanwhile, a limited number of past studies require further research on teacher autonomy to be conducted more vigorously and extensively.

\section{Acknowledgement}

I would like to express my gratitude to my supervisors, my family and friends for all the support, motivation dan contribution throughout my doctorate journey.

\section{Corresponding Author}

Anniliza Mohd Isa

School of Education Studies, Universiti Sains Malaysia, 11800, USM, Pulau Pinang, Malaysia

Email: anniliza@students.usm.my 


\section{References}

Al-Bataineh, O. T., Mahasneh, A. M., \& Al-Zoubi, Z. (2021). The Correlation between Level of School Happiness and Teacher Autonomy in Jordan. International Journal of Instruction, 14(2), 1021-1036. https://doi.org/10.29333/iji.2021.14258a

Al Salami, M. K., Makela, C. J., \& de Miranda, M. A. (2017). Assessing Changes in Teachers' Attitudes toward Interdisciplinary STEM Teaching. International Journal of Technology and Design Education, 27(1), 63-88. https://doi.org/10.1007/s10798-015-9341-0

Ali, A.J., Abdullah, A. G. K., \& Mohammad, I. (2019). Amalan Pengupayaan dan Autonomi Guru dalam Pembelajaran dan Pemudahcaraan Abad ke-21. Jurnal Kepimpinan Pendidikan, 6(Januari), 49-58. https://doi.org/10.1016/j.tca.2018.07.022

BPG. (2015). Persekitaran Pembelajaran Profesional. In Bahagian Profesionalisme Guru (Ed.), Program Transformasi Sekolah 2025 (TS25) (p. Modul 4). Kementerian Pendidikan Malaysia.

Deci, E. L., \& Ryan, R. M. (2008). Self-determination Theory: A Macro Theory of Human Motivation, Development, and Health. Canadian Psychology, 49(3), 182-185. https://doi.org/10.1037/a0012801

Devjak, T., Žmauc, I. J., \& Benčina, J. (2021). The Relationship between the Factors and Conditions of the Autonomy of Preschool Teachers and Fostering the Autonomy of Preschool children in Kindergarten. Center for Educational Policy Studies Journal, 11(1), 67-90. https://doi.org/10.26529/cepsj.712

Duyen, N. T. H. (2019). Teacher Autonomy in Finnish Primary Schools : An Exploratory Study About Class Teachers' Perceptions. Tampere University.

Esfandiari, R., \& Kamali, M. (2016). On the Relationship between Job Satisfaction, Teacher Burnout, and Teacher Autonomy. Iranian Journal of Applied Language Studies, 8(2), 7398. https://doi.org/10.22111/IJALS.2016.3081

Fallis, A. (2005). Teacher-Perceived Autonomy: A Construct Validation of the Teacher Autonomy Scale. Journal of Chemical Information and Modeling, 53(9), 1689-1699. https://doi.org/10.1017/СB09781107415324.004

Guan, L. (2021). Investigation into Improvement of Teacher Autonomy and Student Autonomy through Collaborative Action Research. Theory and Practice in Language Studies, 11(1), 76. https://doi.org/10.17507/tpls.1101.09

Gwatney, K. D. (2012). Teacher Autonomy In The United States: Establishing A Standard Definition, Validation of A Nationally Representative Construct And Investigation of Policy Affected Teacher Group. University of Missouri-Columbia.

Ismail, A., \& Abdullah, A. G. K. (2011). Konsep Asas Dalam Amalan Desentralisasi Pendidikan. Universiti Sains Malaysia.

Ismail, A., \& Abdullah, A. G. K. (2014). Amalan Autonomi dan Akauntabiliti di Sekolah Berautonomi dan Impaknya terhadap Kesediaan Guru. Jurnal Kepimpinan Pendidikan, 1(1), 41-52.

Md. Ali, R., \& Arsaythamby, V. (2017). Teachers' Autonomy and Accountability in Assessing Students' Physical Education in School-Based Assessment. In I. H. Amzat \& N. P. Valdez (Eds.), Teacher Empowerment Toward Professional Development and Practices: Perspectives Across Borders (pp. 71-83). Spinger Nature. https://doi.org/10.1007/978981-10-4151-8

Isa, M. A., Mydin, A., \& Abdullah, A. G. K. (2020). Tranformasi Pendidikan Tahap 1: Peperiksaan ke Pentaksiran Bilik Darjah (PBD), Kesan Terhadap Autonomi Guru. In Isu dan Cabaran 
DEVELOPMENT

Vol. 10, No. 3, 2021, E-ISSN: 2226-6348 @ 2021 HRMARS

dalam Pendidikan: Strategi dan Inovasi (pp. 218-231). Kaizentrenovation Sdn. Bhd.

Isa, M. A., Mydin, A., Ghani, A., Abdullah, K., \& Isa, A. M. (2020). School-Based Management ( SBM ) Practices in Malaysia: A Systematic Literature Review. International Journal of Academic Research in Bussiness \& Social Sciences, 1(9), 822-838. https://doi.org/10.6007/IJARBSS/v10-i9/7870

Moher, D., Liberati, A., Tetzlaff, J., Altman, D., \& The PRISMA Group. (2009). Preferred Reporting Items for Systematic Reviews and Meta-analysis. Plos Med, 6(7). https://doi.org/10.1371/journal.pmed1000097

Paulsrud, D. (2018). Teacher Autonomy in Sweden and Finland Investigating decision-making and Control Comparatively. UPPSALA University.

Paulsrud, D., \& Wermke, W. (2019). Decision-making in Context: Swedish and Finnish Teachers' Perceptions of Autonomy. Scandinavian Journal of Educational Research, $0(0)$, 1-22. https://doi.org/10.1080/00313831.2019.1596975

Pearson, L. C., \& Moomaw, W. (2005). The Relationship between Teacher Autonomy and Stress, Work Satisfaction, Empowerment, and Professionalism. Educational Research Quarterly, 29(1), 38-54. https://doi.org/10.1017/СВ09781107415324.004

Rudolph, L. (2006). Decomposing Teacher Autonomy : A Study Investigating Types of Teacher Autonomy And How it Related To Job Satisfaction. University of Pennsylvania.

Tehrani, I. A., \& Mansor, W. F. A. W. (2012). The Influence of Teacher Autonomy in Obtaining Knowledge on Class Practice. Procedia - Social and Behavioral Sciences, 66, 544-554. https://doi.org/10.1016/j.sbspro.2012.11.299

Ulas, J., \& Aksu, M. (2015). Development of Teacher Autonomy Scale for Turkish Teachers. Procedia - Social and Behavioral Sciences, 186(May 2015), 344-349. https://doi.org/10.1016/j.sbspro.2015.04.023

Vangrieken, K., Grosemans, I., Dochy, F., \& Kyndt, E. (2017). Teacher Autonomy and Collaboration: A Paradox? Conceptualising and Measuring Teachers' Autonomy and Collaborative Attitude. Teaching and Teacher Education, 67(October), 302-315. https://doi.org/10.1016/j.tate.2017.06.021

Varatharaj, R. (2015). Amalan Pentaksiran Dalam PdP Kurikulum Standard Sekolah Rendah (KSSR) Di Sekolah Kluster. Jurnal Penyelidika, 9, 1-17.

Varatharaj, R. (2018a). Assessment in the 21 st Century Classroom: The Need for Teacher Autonomy. International Journal of Research and Innovation in Social Science (IJRISS, 2(6), 105-109.

Varatharaj, R. (2018b). Autonomi : Pandangan dan Penerimaan Guru. Jurnal Penyelidikan Dedikasi, 15.

Varatharaj, R., Abdullah, A. G. K., \& Ismail, A. (2015). The Effect of Teacher Autonomy on Assessment Practices Among Malaysian Cluster School Teachers. International Journal of Asian Social Science, 5(1), 31-36.

https://doi.org/10.18488/journal.1/2015.5.1/1.1.31.36

Zhou, Q., Li, Q., \& Gong, S. (2019). How Job Autonomy Promotes Employee's Sustainable Development? A Moderated Mediation Model. Sustainability (Switzerland), 11(22), 114. https://doi.org/10.3390/su11226445 